\title{
Women's Language Used by Female Characters in the Movie How To Be Single
}

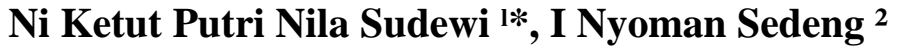 \\ ${ }^{[12]}$ English Department - Faculty of Arts - Udayana University \\ 1[putrinila383@gmail.com] 2 [nyoman_sedeng@hotmail.com] 3[moelya01@gmail.com] \\ *Corresponding Author
}

\begin{abstract}
This undergraduate thesis entitled Women's Language Used by Female Characters in The Movie How To Be Single. It is aimed at identifying the language features applied by female characters and finding out the functions of each type of women's linguistic features. This paper used the theory of women's linguistic features proposed by Robin Lakoff (1975). The data source in this study is the movie How To Be Single. The collected data were identified and selected, then the features of women's language used by the female characters in the movie How To Be Single were analyzed based on Lakoff (1975). The method applied in collecting data was the documentation method. Afterwards, the method of analyzing data in this study was the descriptive qualitative method. This study applied informal method in presenting the data analysis. The findings of the analysis showed that there were nine kinds of women's linguistic features found in the movie How To Be Single. There were also some functions of women's linguistic features found in the data. The functions of each type of the features are closely related to the context in which it is used. Each type of women's linguistic features found in the movie displays has different functions and reasons.
\end{abstract}

Keywords: women's language, women's linguistic features, women' language function.

\section{Abstrak}

Skripsi ini berjudul "Bahasa Wanita yang digunakan oleh Karakter Perempuan di Film How To Be Single”. Tujuan penelitian ini adalah untuk mengidentifikasi bahasa perempuan yang digunakan oleh karakter wanita dan mengetahui fungsi dari masingmasing fitur tersebut. Teori yang digunakan dalam penelitian ini yaitu teori menurut Robin Lakoff (1975). Data yang digunakan dalam penelitian ini bersumber dari film How To Be Single. Metode yang digunakan dalam pengumpulan data adalah metode dokumentasi dan metode analisis yang digunakan adalah metode deskriptif kualitatif. Penelitian ini menggunakan metode informal dalam menyajikan analisis data, yaitu merepresentasikan hasil analisis dengan menggunakan kata-kata. Hasil penelitian ini menunjukkan ada sembilan jenis fitur wanita yang ditemukan beserta dengan fungsi dari fitur-fitur tersebut. Setiap jenis fitur bahasa wanita yang dianalisis memiliki fungsi dan alasan yang berbeda. Secara umum, fungsi dari bahasa wanita yang digunkan bertujuan untuk bersikap sopan dan menghindari ekspresi yang kuat.

Kata kunci: Bahasa Wanita, Fitur Bahasa Wanita, Fungsi Bahasa Wanita 


\section{Background of the Study}

Language is the most important means of communication for human beings. Many definitions of language have been proposed. According to Henry Sweet (1988), language is the expression of ideas by means of speech-sounds combined into words. The difference in language use between men and women brings influence on their language in use. Between men and women, both have their own typically style of speaking. Hornby (1995) claimed many societies have negative stereotypes related to women and language. Moreover, Oxford Advance Learner's Dictionary defines woman as adult female of human being. The term "woman" is usually for an adult female, whereas "man" is an adult male human being or male person with the qualities of strength, courage and others. Holmes (1992: 33) stated that female are more linguistically polite than male and both male and female emphasize different speech functions. She said that female used standard form of prestigious form, while male used vernacular form, which does not have social status and not citied as the correct form.

Many sociolinguists suggest that men and women speak differently in any community. Women have their own characteristics which men do not have. Physical appearances and voice qualities are the two things which differentiate men from women which can be seen clearly.Women language is very interesting subject to be studied as related to the variation of gender as the main parameter in the language use. This study analyzed the women's linguistic features and their functions as represented by women's characters in the movie How To Be Single. It is an interesting movie because it contains many teachable and valuable messages such as women's friendship and education.

\section{Problem of the Study}

According to the background above, the problems of this study are :

a. What kinds of women's linguistic features are found in the movie How To Be Single?

b. What are the functions of those women's linguistic features found in How To Be Single movie?

\section{Aims of the Study}

The aims of the study are classified into two parts:

a. To identify the kinds of women's linguistic features used in the movie How To Be Single .

b. To find out the women's language functions in the movie How To Be Single.

\section{Research Method}

The data source in this study was taken from the movie How To Be Single . The main data of this study were the utterances of the female characters in the movie How To Be Single.

The method applied in collecting data was the documentation method. There were some steps to collect data in this study: first, watching and observing every utterance in the movie How To Be Single. Second, listening to and comparing between the subtitle and the conversations in the movie How To Be Single to make the data more effective. Lastly, twenty six data were selected from the utterances produced by female characters based on the theory of women's language proposed by Lakoff (1975).

The method of analyzing data in this study was the descriptive qualitative method. This study analyzed twenty six data of women's linguistic features and functions used in the conversations in the movie How To Be Single. The data were analyzed based on the theory of women's linguistic features proposed by Lakoff 
(1975). There were some techniques in analyzing the data in this study, first the data were identified and selected, the features of women's language spoken by the female characters in the movie How To Be Single movie were analyzed and the last step was analyzing the function of women's linguistic features proposed by Lakoff (1975).

This study applied informal method in presenting the data, which presents the result of analysis using words and it is intended to make the readers more understand the topic.

\section{Findings and Discussion}

\subsection{The Analysis of Women's Linguistic Features and Functions}

\subsubsection{Lexical Hedges or Fillers}

Data (1)

Meg : Okay, let's go to your happy place.

Patient : What if I poop?

Meg : I won't even notice. Oh, God. It's totally natural. Women have been doing this for thousands of years, okay?

Patient : How many babies have you had?

Meg : Well, I've delivered about 3,000 of them.

The hedge well in Meg utterance is used to express her uncertainty that she is not sure how many babies have been delivered. The function of hedge well in Meg utterance is used to show her uncertainty or cannot vouch for the accuracy of the statement.

\subsubsection{Tag Question}

Data (7)

Tom : What are you really doing online? I mean, you're a pretty girl. This is New
York City. There's like a billion people outside that door.

Lucy : Yeah, but how many eligible people? Here. Okay, there are eight million people in this city. Sounds like a lot, right?

Tom : It does.

The function of tag question in Lucy utterance is used to show uncertainty about her utterance as well as to seek for confirmation. This utterance is less assertive than a statement, but more confident than question, it can be categorized as a tag question.

\subsubsection{Rising or Question Intonations on Declarative}

Data (8)

Robin :Your roommate seems pretty cool

Alice : Oh, she's my sister.

Robin : Really? Mmm-hmm. Uh, then I think I might have pissed in your sister's litter box.

Robin used rising intonation really? in her utterance to show that she was surprised when she saw Meg set on the sofa with a cup of coffee. The function of rising intonation in Robin utterance is used to seek for confirmation.

\subsubsection{Empty Adjective}

Data (11)

Tom : Hey, listen. I hope, uh, that kiss wasn't too much.

Lucy : Oh, my God. No, no, that was awesome!

Lucy used empty adjectives awesome! in her utterance when Tom kissed her suddenly in the bar. Lucy used empty adjective in her utterance to indicate her admiration that Tom was very brave to kiss her in front of her friend's. 


\subsubsection{Hypercorrect Grammar}

Data (16)

Josh : I don't think it's coming out like it's inside your head.

Alice : Josh. I want to be alone. I know that I've said that a lot. But, for the first time in my life, I really, really, truly mean it. Congratulations on your engagement.

Alice used hypercorrect grammar really in her utterance when she talked with Josh. Alice spent so much time waiting for Josh, but suddenly Josh told her that he would get married with someone else. The function of hypercorrect grammar in Alice utterance was to show her politeness.

\subsubsection{Super polite Form}

Data (17)

Meg: Who told you that?

Alice: The slider guy. Please blink, so I know you're in there.

Meg : I'm sorry. I just have blood pumping through my body in an uncomfortable way and it feels like it's all accumulating right here.

Meg uttered I'm sorry in her utterance because she felt uncomfortable with her stomach. She uttered sorry to apologize in a polite way because she didn't give any response directly. The function of super polite form in data (17) above was to apologize in a polite way.

\subsubsection{Intensive Adverbs}

Data (21)

Alice : Well, okay, technically, I'm not, like, single. We're just on a break.

Robin: Uh, there's no such thing as a "break," Season-3 Ross.

Alice : No, we really are on a break. We're just taking a little bit of time apart to make sure we really want to be together.

In that situation Alice gave the reason that she was not single and she just wanted a little time to take a break in her relationship with Josh. The function of the intensifier just in Alice's utterance was to strengthen her assertion in her statement so that she could be trusted by Robin.

\subsubsection{Avoidance of Strong Swear Words}

Data (24)

Meg : I found a sperm donor. This guy. He's of Swedish descent.

Alice : Oh, my God.

Meg : He has no known cancers on either side of his family, no history of drug abuse, no history of any kind of mental illness, or...

Alice : Oh, my God.

Meg : I know.

Alice : Oh, my God.

Alice used avoidance of strong swear words oh my God in her utterance. It could be seen that her utterance functions to show how strongly they were allowed themselves to feel about something.

\subsubsection{Emphatic Stress}

Data (25)

Alice : Oh, my God. This is amazing.

David : Thank you.

Alice : I've always wanted to see this.

David : Yeah

Alice used the emphatic stress amazing in her utterance. She was surprised when David takes her to see the Rockefeller trees from the top of his apartment. Alice used the emphatic stress amazing in her utterance to make the word sound in a great extent that she was really surprised.

\section{Conclusion}

The discussion focuses on two problems mentioned in the previous chapter such as language features and 
their functions applied by women. Based on the analysis and discussion, there are some points presented as the conclusions of the study.

First, there are nine features of women's linguistic features found in the movie How To Be Single movie. Second, there are some functions of women's linguistic features found in the data. Functions of each type of the features are closely related to the context to which it is used. Each type of women's linguistic features found in the movie displays has different functions and reasons. In general, the finding of the analysis of functions is intended to be polite and avoid strong expressions. Among ten linguistic features proposed by Lakoff (1975), only one feature precious was not found in the data.

\section{References}

Holmes, Janet. (1992). An Introduction to Sociolinguistics. Longman, New York.

Hornby,A.S. (2005). Oxford Advanced Learner's Dictionary $7^{\text {th }}$ Edition. Oxford University Press, Oxford.

Lakoff, Robbin. (1975). Language and Women's Place. Harper \& Row, New York

Sweet, Henry. (1988). Comparative Linguistcs, Language and Languages. Dent, London. 